\title{
SPIRITUALITAS DAN PESANTREN SPIRITUAL DZIKRUSSYIFA ASMA BEROJOMUSTI LAMONGAN
}

\author{
SPIRITUALITY AND DZIKRUSSYIFA ASMA \\ BEROJOMUSTI LAMONGAN SPIRITUAL PESANTREN
}

\author{
Husen Hasan Basri \\ Puslitbang Pendidikan Agama dan Keagamaan \\ Badan Litbang dan Diklat Kementerian Agama RI \\ Jl. MH Thamrin No. 06 Jakarta Pusat, Email: hhasanbasri@yahoo.com
}

\begin{abstract}
The attachment of spiritualism to pesantren is nothing new in the world of pesantren but the phenomenon of labeling of "spiritual pesantren" by the founder is something new. One of the pesantren explicitly using the term "spiritual" is Dzikrussyifa" Asma' Berojomusti spiritual pesantren. This study examines why Dzikrussyifa' is named a spiritual pesantren while the term pesantren has contained the values of spirituality. Through qualitative method it is found that the foundation of Dzikrussyifa' pesantren aims to fill, respond a space that has not been optimally filled by other pesantren. The founder would like to offer the paradigm of a pesantren oriented to "spirituality" referring to the Walisongo pesantren. Dzikrussyifa' pesantren is the concrete understanding of the meaning of spirituality influenced by Islamic Sufism and Walisongo Sufism. The spirituality meaning is actualized in all activities in the pesantren from its objective, students, lecturers and subjects. It is concluded that the meaning of spirituality is close to the understanding of the term Sufism or the more practical aspect of Sufism namely tarekat. Its meaning of spiritualism is influenced by Sunni tasawuf. Dzikrussyifa' pesantren takes the path of populist spirituality or tarekat rakyat to fill the model of tasawuf considered non-optimum.
\end{abstract}

Key Words: Spirituality, Tasawuf, Spiritual Pesantren

\begin{abstract}
Abstrak
Spiritual dijadikan predikat oleh sebuah pesantren bukan hal baru dalam dunia ke pesantrenan. Tetapi terdapat fenomena pesantren yang diberi label oleh pendirinya dengan sebutan "pesantren spiritual". Salah satu pesantren yang secara eksplisit menggunakan kata "spiritual" adalah Pesantren Spiritual Dzikrussyifa' Asma' Berojomusti. Mengapa Pesantren Dzikrussyifa' diberi predikat "spiritual", bukankah dalam istilah pesantren sendiri mengandung nilai-nilai spiritualitas. Melalui metode kualitatif ditemukan bahwa pendirian pesantren Dzikrussyifa' adalah untuk mengisi, merespon, menanggapi sebuah ruang yang belum maksimal diperankan oleh pesantren-pesantren lainnya. Pendiri Pesantren Dzikrussyifa' ingin menawarkan sebuah paradigma pesantren yang berorientasi "spiritual" dengan pijakan ala pesantren Wali Songo. Eksistensi Pesantren Dzikrussyifa' adalah hasil konkret yang dipengaruhi dari pemaknaan sang pendiri terhadap arti spiritualitas yang dipengaruhi oleh para sufi dunia Islam dan sufistik ala Wali Songo. Pemaknaan spiritualitas tersebut diwujudkan dalam seluruh bentuk aktivitas di pesantren. Disimpulkan bahwa pemaknaannya terhadap spiritualitas lebih dekat kepada pemahaman istilah sufisme (tasawuf) atau dengan aspek yang lebih praktis dari tasawuf, yakni tarekat. Pemaknaannya terhadap spiritualitas dipengaruhi oleh tasawuf Sunni. Pesantren Dzikrussyifa' mengambil jalan "spiritual kerakyatan" atau "tarekat rakyat" dalam rangka mengisi model tasawuf yang terasa kurang daya dorongnya.
\end{abstract}

Kata Kunci: Spiritualitas, Tasawuf, Pesantren Spiritual

Naskah diterima 27 Februari 2015. Revisi pertama, 14 Maret 2015. Revisi kedua, 19 Maret 2015 dan revisi terahir 3 April 2015 


\section{PENDAHULUAN}

Kemunculan fenomena pesantren yang diberi label oleh pendirinya dengan sebutan "pesantren spiritual" mengingatkan kembali kepada model Wali Songo dalam penyebaran dan penanaman ajaran Islam di Jawa melalui pendekatan tasawuf 1 dan "pesantren". Perpaduan antara pendekatan tasawuf dan "pesantren" kemudian menjadi-meminjam istilah Lombard-jaringan-jaringan Islam yang agraris dari unsur-unsur penggerak dalam Islam Jawa. ${ }^{2}$

Sebenarnya spiritual dijadikan predikat oleh pesantren bukan hal baru dalam dunia ke pesantrenan. Menurut Muhammad Tholhah Hasan, pesantren sejak masa Wali Songo pada abad 15 M sampai sekarang diwarnai oleh aktivitas spiritual (ruhiyah) baik yang dipraktikkan oleh peminat khusus (khawas) dari para anggota tarekat maupun yang dipraktikkan oleh kalangan umum ('awam) dari para santri dengan kegiatan praktis sehari-hari seperti zikir, puasa sunah, wirid, hidup zuhud, berlaku sopan, menghormati guru, sabar, istikamah, dan lain-lain. ${ }^{3}$

1 A.H. John. 1961. "Sufism as a category in Indonesian Literature and History", dalam JSEAH, 2. Lihat juga M.C. Ricklefs. 2012. Mengislamkan Jawa: Sejarah Islamisasi di Jawa dan Penentangnya dari 1930 sampai Sekarang. Jakarta: PT Serambi Ilmu Semesta.

${ }^{2}$ Selain jaringan-jaringan Islam agraris, unsurunsur penggerak dalam Islam Jawa adalah orang laut dan kalangan-kalangan "borjuis" pengusaha. Lihat Denis Lombard. 2005. Nusa Jawa: Silang Budaya, Bagian II Jaringan Asia. Jakarta: Gramedia Pustaka Utama, h. 84-148.

${ }^{3}$ Dikutip dari transkrip paparan Muhammad Tholhah Hasan yang berjudul "Pesantren dan Sikap Inklusivisme Neosufisme" yang disampaikan dalam acara Halaqoh Ulama dengan tema Pesantren Sebagai Pusat Peradaban Islam yang dilaksanakan oleh Puslitbang Pendidikan Agama dan Keagamaan di Bogor, 13-14 Desember 2010
Membicarakan spiritualitas di pesantren sebenarnya tidak lain membahas hubungan pesantren dan tasawuf, karena tasawuf sendiri merupakan kelembagaan spiritualitas Islam. Namun dalam tradisi pesantren istilah tasawuf dipakai dalam kaitan aspek intelektual, sedangkan aspekaspeknya yang bersifat etis dan praktis diistilahkan dengan sebutan tarekat. ${ }^{4}$ Tidak banyak pesantren yang menjadi pusat gerakan tarekat dan yang mengkhususkan diri dalam bidang tasawuf sebagai objek pengajarannya. Bruinessen menyebutkan sekitar tahun 1970 terdapat empat pusat tarekat Qadiriyah wa Naqsabandiyah yang penting di pulau Jawa: Rejoso Jombang dengan Kiai Musta'in Romly, Mranggen dengan Kiai Muslikh, Suryalaya Tasikmalaya dengan K.H. A. Shohibulwafa Tajul 'Arifin (Abah Anom), dan Pagentongan Bogor dengan Kiai Thohir Falak. ${ }^{5}$

Pesantren-pesantren yang menjadi pusat gerakan tarekat yang memiliki jalur ke tarekat Qadiriyah wa Naqsabandiyah di antaranya: Pesantren Al-Fithrah Kedinding Kenjeran Surabaya pimpinan KH Asrori Al-Ishaqi (wafat 18 Agustus 2009). Syekh Usman Al-Ishaqi, ayah KH Asrori, adalah salah satu murid KH Romli Tamim, ayah KH Musta'in Romli, Rejoso Jombang, dan Pesantren Suryalaya Tasikmalaya pimpinan

${ }^{4}$ Zamakhsari Dhofier. 1982. Tradisi Pesantren: Studi tentang Pandangan Hidup Kiai. Jakarta: LP3ES, h. 135

${ }^{5}$ Martin Van Bruinessen. 1999. Kitab Kuning, Pesantren dan Tarekat: Tradisi-Tradisi Islam di Indonesia. Bandung: Mizan, h. 21. Rejoso, Mranggen, Suryalaya, Pagentongan adalah nama-nama pesantren yang dipimpin oleh kiai-kiai tersebut, dan merupakan karakteristik pesantren salafiyah atau tradisional yang menamakan pesantrennya dengan nama daerah dimana pesantren-pesantren itu berada. 
Abah Anom. Pesantren ini sering dikenal oleh publik sebagai pusat pengobatan bagi pecandu narkoba. ${ }^{6}$ Sepeninggal Abah Anom September 2011, sesepuh pesantren diteruskan oleh KH. Zaenal Abidin Anwar sekaligus pengemban amanah untuk memimpin tarekat Qadiriyah wa Naqsabandiyah.

Salah satu pesantren-bisa juga satusatunya-yang secara eksplisitmenggunakan kata "spiritual" adalah Pesantren Spiritual Dzikrussyifa' Asma' Berojomusti (selanjutnya ditulis Pesantren Dzikrussyifa'). Pesantren yang dipelopori dan sekaligus dipimpin oleh Kiai Muhammad Muzakkin merupakan kebutuhan masyarakat (orang yang sakit jiwa dan pecandu narkoba) yang menginginkan pengobatan dengan cara spiritual. Pesantren yang didirikan pada 5 Januari 2000 terletak di dusun Sekanor desa Sendangagung kecamatan Paciran Lamongan.

Jika Pesantren Suryalaya dan pesantrenpesantren lainnya yang menjadikan tarekat sebagai pusat pengajaran tidak secara eksplisit menggunakan kalimat "spiritual" dalam nama pesantrennya, meskipun S. Soebardi menyebut pesantren Suryalaya dengan sebutan "pesantren tarekat Suryalaya”, 7 maka Pesantren Dzikrussyifa' menambah kata "spiritual", bahkan dalam papan nama dan logo surah ditambah frase "khusus rehabilitasi sakit jiwa dan pecandu narkoba". Frase ini mungkin untuk mengaitkan dengan kata "Dzikrussyifa"

6 Nurcholis Madjid. 1974. "Tasawuf dan Pesantren", dalam Dawam Rahardjo (ed), Pesantren dan Pembaharuan. Jakarta: LP3ES, h. 105.

7 S. Soebardi. 1978. "The Pesantren Tarikat of Suralaya”, dalam S.Udin (ed), SPECTRUM. Jakarta: Dian Rakyat. yang memiliki arti ingat dan obat. Kalimat “Asma' Berojomusti” sendiri mengesankan adanya term Jawa yang dikaitkan dengan ilmu kebatinan atau kekebalan.

Ada harapan dari pimpinan untuk menjadikan Pesantren Dzikrussyifa' sebagai barometer kegiatan keagamaanyang bersifat pendidikan supranatural di kawasan Pantai Utara Jawa (Pantura). Mungkin harapan dari pimpinan inilah yang membuat kalangan media menyebut Pesantren Dzikrussyifa' sebagai Pesantren Jin". ${ }^{8}$ Meskipun dibantah oleh pihak pengasuhnya, salah satu pesantren yang oleh media sering dikaitkan dengan "jin" dalam pembangunannya adalah Pesantren Salafiyah Bihaaru Bahri Asali Fadlaailir Rahmah Turen Malang Jawa Timur. Pesantren ini oleh masyarakat disebut Masjid Tiban. ${ }^{9}$

Mengapa Pesantren Dzikrussyifa' diberi predikat "spiritual", bukankah dalam istilah pesantren sendiri mengandung nilainilai spiritualitas. Memang pesantren itu memiliki potensi spiritual (baca-tasawuf) untuk memberikan perbaikan moral dan

8 Beberapa media online memberikan judul beritanya tentang Pesantren Dzikrussyifa' sebagai berikut. Merdeka.com, Minggu, 13 April 2014 dengan judul "Puluhan Caleg Stres Terapi di Pondok Pesantren Jin di Lamongan"; Merdeka. com, Sabtu, 3 Mei 2014 dengan judul "Mengintip pesantren 'Jin' di Lamongan Yang Obati 58 Caleg Stres"; Tempo.co, Senin 14 April 2014 dengan judul "Kiai Muzakkin Gunakan Jin Obati Caleg Stres"; Kompas.com, Rabu, 26 Agustus 2009 dengan judul "Wah, Ada Pengajian Khusus Bangsa Jin di Lamongan”; Kompas.com, Minggu, 27 September 2009 dengan judul "Jin dari Mesir pun Nyantri di Lamongan"; Okezone.com, Senin, 7 September 2014 dengan judul "Ramadan, Giliran Jin Diasuh di Ponpes Berojomusti"; Detiksurabaya. com, Rabu, 9 Desember 2009 dengan judul "Seribu Jin Amankan Hari Antikorupsi”.

${ }^{9}$ http://www.ponpesbibaafadlrah.or.id/indexp. php?p=profile_pengasuh 
karakter, namun sebagaimana diungkap oleh M.Tholhah Hasan bahwa di pesantren daya tahan tasawuf lebih dominan dari pada daya dorongnya. Pendirian Pesantren Dzikrussyifa' untuk mengisi, merespons, menanggapi sebuah ruang yang belum maksimal diperankan oleh pesantren-pesantren lainnya. Pendiri Pesantren Dzikrussyifa' ingin menawarkan sebuah paradigma pesantren yang berorientasi "spiritual" dengan pijakan ala pesantren Wali Songo. Eksistensi Pesantren Dzikrussyifa' adalah hasil konkret yang dipengaruhi dari pemaknaan sang pendiri terhadap arti spiritualitas.

Sebenarnya, seperti apakah Pesantren Dzikrussyifa'? Apa makna spiritual yang melekat dalam nama Pesantren Dzikrussyifa'? Sejauh mana pemaknaan label spiritual itu memengaruhi proses kegiatan di Pesantren Dzikrussyifa?_Karena itu, diperlukan sebuah penelitian empirik agar dapat memberikan gambaran tentang eksistensi Pesantren Dzikrussyifa' yang memberi label "spiritual" itu relasinya dengan gerakan spiritualitas Islam (tasawuf) di masa lalu.

Dari latar belakang masalah tersebut, ada dua fokus masalah penelitian berkaitan dengan fenomena Pesantren Dzikrussyifa' yang ingin dijawab dalam penelitian ini, yaitu: pertama, apa makna spiritualitas menurut pimpinan Pesantren Dzikurussyifa'? dan apakah terdapat satu model spiritual yang memengaruhi pemaknaan spiritualitas tersebut? dan kedua, sejauh mana pemaknaan spiritualitas tersebut memengaruhi aktivitas Pesantren Dzikrussyifa'?.
Penelitian ini bertujuan untuk mendeskripsikan: pertama, makna spiritualitas menurut pimpinan Pesantren Dzikrussyifa' dan model spiritual yang memengaruhi pemaknaan spiritualitas, dan kedua, pengaruh pemaknaan spiritualitas terhadap aktivitas Pesantren Dzikrussyifa'.

Penelitian ini diharapkan dapat melengkapi studi tentang hubungan pesantren dan potensi tasawuf. Penelitian ini diharapkan dapat digali spiritual ala pesantren dalam pengembangan pendidikan karakter dan pendidikan akhlak yang saat ini menjadi isu yang hangat diperbincangkan. Melalui penelitian ini juga diharapkan dapat diperoleh bahan pemikiran untuk menjadi pijakan dalam pengembangan pesantren.

\section{Kerangka Konseptual}

Spiritualitas telah menjadi tema menarik di saat hidup dan kehidupan mengalami perkembangan yang sangat cepat. Istilah spiritualitas mengandung beberapa pengertian baik secara kebahasaan maupun secara terminologi. Secara kebahasaan perkataan spiritualitas berasal dari perkataan spirit yang berarti roh, jiwa, semangat atau keagamaan. Jadi, spiritualitas secara kebahasaan bisa diartikan sebagai segala aspek yang berkenaan dengan jiwa, semangat, dan keagamaan yang memengaruhi kualitas hidup dan kehidupan seseorang. Dalam Encyclopedia Americana disebutkan bahwa istilah spiritualitas atau spiritualism kadang-kadang digunakan dengan mengacu kepada sebuah aliran filsafat manusia, lawan dari aliran materialism. Kadang-kadang, istilah spiritualism digunakan untuk menunjuk sebuah sekte agama atau kelompok umat beragama dari kalangan Kristen yang 
menekankan doktrin bahwa ruh orang yang sudah mati masih hidup sebagai seorang pribadi yang dapat berkomunikasi dengan orang yang masih hidup melalui seorang yang dikenal sebagai medium. Istilah Spiritualitas adalah dimensi batin (esoteric dimension) atau jiwa agama dalam kehidupan manusia. Spiritual Islam disebut tasawuf, di barat orang menyebutnya Islamic Mysticsm atau sufism. ${ }^{10}$

Tasawuf sebenarnya sudah berkembang pada zaman Nabi tapi sebutan tasawuf itu baru ada pada akhir abad ke 1 Hijriyah atau pada awal abad ke-2 Hijiriyah. ${ }^{11}$ Tasawuf sebagai sebuah gerakan diawali oleh gerakan zuhud dan 'uzlah yang dipelopori oleh Hasan al-Basri (w.110 H/728 M), Rabi'ah Adawiyah (w.185 H/801 M) dan Ibrahim bin Adham (w. 159 H/777 M). Kehidupan model zuhud kemudian berkembang pada abad ke-3 Hijriyah ketika kaum sufi mulai memperhatikan aspek-aspek teoritis psikologis dalam rangka pembentukan perilaku hingga tasawuf menjadi sebuah ilmu akhlak keagamaan. Pemikiran-pemikiran yang lahir selanjutnya terlibat dalam masalah-masalah epistemologis. Masalahmasalah ini berkaitan langsung dengan pembahasan mengenai hubungan manusia dengan Allah SWT, sehingga lahir konsepsikonsepsi seperti fana', terutama oleh Abu Yazid Al-Busthami (w. $261 \mathrm{H} / 874$ M). Tasawuf kemudian menjadi sebuah ilmu setelah sebelumnya hanya merupakan ibadah-ibadah praktis. Pada abad ke-3 dan

10 Lihat Muchlis Hanafi, et.al (editor). 2010. Spiritualitas dan Akhlak. Jakarta: Lajnah Pentashihan Mushaf Al-Qur'an Badan Litbang Dan Diklat Kementerian Agama, h. 471 dan 445

${ }^{11}$ Transkrip paparan Muhammad Tholhah Hasan, "Pesantren dan Sikap Inklusivisme Neosufisme", hal. 1 ke-4 H muncul tokoh-tokoh tasawuf seperti Al-Junaid (w.910 M) dan Sari Al-Saqathi (w.867 M) serta Al-Kharaj (w.899 M) yang memberikan pengajaran dan pendidikan kepada para murid dalam sebuah bentuk jamaah. Pada periode ini muncul pula jenis baru tasawuf yang diperkenalkan Al-Husain ibn Manshur Al-Hallaj (w.921 M) yang dihukum mati akibat doktrin hulul-nya. ${ }^{12}$

Pada abad ke-5 Imam Al-Ghazali (10591111 M) tampil menentang jenis-jenis tasawuf yang dianggapnya tidak sesuai dengan Al-Qur'an dan as-Sunnah dengan mengembalikan tasawuf kepada status semula sebagai jalan hidup zuhud, pendidikan jiwa dan pembentukan moral. Tasawuf semacam ini disebut tasawuf Sunni. ${ }^{13}$ Sejak tampilnya Al-Ghazali, pengaruh tasawuf Sunni mulai menyebar di Dunia Islam. ${ }^{14}$ Bahkan muncul tokoh-tokoh sufi terkemuka yang membentuk tarekat untuk mendidik para murid, seperti Syaikh Ahmad Rifa'i (w.570 H) dan Syaikh 'Abd AlQadir Jailani (w.651 H/1166 M) yang sangat

12 Alwi Shihab. 2009. Antara Tasawuf Sunni \& Tasawuf Falsafi: Akar Tasawuf di Indonesia. Depok: Pustaka Iman, h. 45

${ }^{13}$ Ibid. h. 50

14 Pemikiran keagamaan Al-Ghazali tidak hanya berpengaruh di kalangan Islam, tetapi juga di kalangan Yahudi dan Kristen. Pengaruh Al-Ghazali dalam pemikiran Yahudi dengan tampilnya Filsuf Yahudi, Musa Ibn Maymun (Moses the Maimonides) melalui karya al-Munqidz min al-Dlalal, persis judul sebuah kitab al-Ghazali. Pengaruh al-Ghazali di kalangan Kristen melalui filsafat Bonaventura. Pandangan sufisme al-Ghazali memperoleh salurannya dalam mistisime Kristen Katolik melalui Ordo Fransiscan seperti diungkapkan dalam novel best seller nya Umberto Eco, The Name of the Rose. Lihat Nurhcolis Madjid. 2009. Kaki Langit Peradaban Islam. Jakarta: Paramadina bekerjasama dengan penerbit Dian Rakyat, khususnya bagian "Pandangan TasawufFalsafi Imam Al-Ghzali”, h. 89-90 
terpengaruh oleh garis tasawuf Al-Ghazali. Pilihan yang sama dilakukan generasi berikut, antara lain yang paling menonjol adalah, Syaikh Abu Hasan Al-Syadzili (w.650 H) dan muridnya, Abu Al-'Abbas Al-Mursi (w. 686 H), serta Ibn 'Atha'illah Al-Sakandari (w. $709 \mathrm{H}) .^{15}$

Sejumlah sufi pada abad ke-6 H yang berorientasi filsafat, antara lain: Suhrawardi Al-Maqtul, tokoh ilmu huduri atau presensial (w. $587 \mathrm{H}$ ), Ibn 'Arabi (w.638 H), penyair sufi Mesir, Umar Ibn Al-Faridh (w.632 H), dan 'Abd Al-Haq Ibn Sab'in (w. 669 H). Dalam aliran mereka berkembang panteisme (wahdatul Wujud) yang mengarahkan tasawuf pada "kebersatuan" dengan Allah. ${ }^{16}$ Kemunculan aliran tersebut menjadikan tasawuf terbagi dua, yaitu: pertama, tasawuf Sunni yang dikembangkan para sufi pada abad ke-3 dan ke-4 yang disusul AlGhazali dan para pengikutnya dari syaikhsyaikh tarekat. Kedua, tasawuf falsafi yang menggabungkan tasawuf dengan berbagai aliran mistik dari lingkungan di luar Islam, seperti dalam Hinduisme, kependetaan Kristen atau teosofi dalam neo-Platonisme. Kedua jenis tasawuf baik Sunni maupun falsafi berkembang di Indonesia.

Model tasawuf Sunni banyak dianut oleh pelopor dan pemimpin dakwah Islam Indonesia-termasuk Walisongo. Adanya pengaruh Al-Ghazali yang berakar kuat dalam pemikiran tasawuf Walisongo, terutama disebabkan karena pencetus tarekat mereka, Al-'Alawiyah, yakni Syaikh AlImam 'Abdullah ibn Al-Imam Ahmad AlMuhajir adalah leluhur Walisongo. Faktor

${ }^{15}$ Alwi Shihab. 2009. Antara Tasawuf Sunni \& Tasawuf Falsafi..., h. 50-51

${ }^{16}$ Ibid. h. 51 lain yang ikut menentukan pengaruh AlGhazali terhadap tasawuf Walisongo adalah karena salah seorang pemimpin tarekat Al-'Alawiyah, yakni Imam Muhammad ibn 'Ali dengan gelar Al-Faqih Al-Muqadam (pemimpin ahli fikih) memiliki kesamaan dengan Al-Ghazali. Dari Muhammad ibn 'Ali inilah Walisongo mengambil metode dan cara dakwahnya. Dan, dari segi akidah Walisongo mengikuti faham Asy'ariyah. ${ }^{17}$

Spiritualitas Walisongo berisikan kearifan dan kemampuan spirit Islam sehingga dapat berbicara sesuai dengan kapasitas para audiennya. Mereka melakukan modifikasi adat istiadat dan tradisi setempat sedemikian rupa agar tidak bertentangan dengan dasardasar Islam. Ada yang mengatakan bahwa Islam tidak akan pernah menjadi the religion of Java jika sufisme yang dikembangkan oleh Walisongo tidak mengakar dalam masyarakat. ${ }^{18}$ Walisongo terlibat secara fisik dalam peran serta sosial untuk memetakan dan sekaligus memecahkan permasalahan masyarakat, dan untuk memberikan contoh ideal dan religius kemasyarakatan. Pentingnya tentang modeling Walisongo, Abdurahman Mas'ud menyatakan:

...Usaha Maulana Malik Ibrahim (w. 1419 di Gresik, Jawa Timur), untuk melembagakan metode pendidikan yang pada masa-masa berikutnya dikenal sebagai "pesantren". Guna mengantisipasi dan mengakomodir pertanyaan-pertanyaan sosial keagamaan serta dalam rangka menghimpun anggota, Ibrahim menggunakan sistem pesantren. Tidaklah sulit baginya untuk mendirikan sebuah pesantren, se-

${ }^{17}$ Ibid. h. 30-31 dan 34

${ }^{18}$ Lihat Abdurahman Mas'ud. 2006. Dari Haramain Ke Nusantara: Jejak Intelektual Arsitek Pesantren. Jakarta: Kencana Prenada Media Group, h. 57 
bab ia telah memiliki banyak pengikut setia serta kekayaan dari hasil usaha dagangnya. Dilaporkan bahwa seharian penuh, dia membawa masyarakatnya ke lahan pertanian, sementara malam harinya dia mengajar mereka pelajaran-pelajaran dasar, khususnya Al-Quran dan Hadits di lembaganya ini. Karena caranya berdakwah inilah dia disebut sebagai bapak atau guru pesantren masa awal di Jawa. Pada saat yang sama dia juga merupakan bapak spiritual dari Walisongo. ${ }^{19}$

Deskripsi di atas memperlihatkan bahwa spiritual Walisongo menjalankan ajaran Islam model Nabi Muhammad, dan mengajarkannya melalui jalan sufistik yang tidak bertentangan dengan ajaran model Nabi Muhammad serta mengakomodir tradisi dan kebiasaan lokal. Spiritual Walisongo juga adalah "keteladanan yang baik" sebelum "berucap kata".

Meskipun tumbuhnya pesantren atau pondok dapat ditelusuri ke belakang sebagai bermula dari sistem zawiyah kaum sufi yang dikembangkan, tetapi kenyataan sekarang tidak berarti setiap pesantren merupakan pusat gerakan tasawuf. Sekarang ini pesantren lebih dikenal sebagai lembaga pendidikan dan pengajaran. Sedangkan yang melakukan peranan sebagai pusat gerakan tarekat hanya sedikit saja. Lebih sedikit lagi ialah pesantren yang mengkhususkan diri dalam bidang tasawuf sebagai objek pengajarannya. Sufisme di Indonesia agaknya lebih terbatas kepada segi-seginya yang praktis saja, sedangkan segi pemikiran kontemplatifnya sangat kurang. Karena itu perkataan "tarekat" adalah lebih dikenal daripada perkataan tasawuf, khususnya di

\footnotetext{
${ }^{19}$ Ibid., h. 62
}

kalangan para pengikut awam yang merupakan bagian terbesar.

Tasawuf di pesantren yang berpegang kepada doktrin-doktrin ortodoks yang menjauhkan daripanteisme dansebangsanya itu adalah berkat dijadikannya ajaranajaran Imam Al-Ghazali sebagai pegangan pokok. Tolkhah Hasan menyebut bahwa tasawuf-tasawuf yang masuk di Indonesia dan di pesantren adalah 95\% Tasawuf Sunni. Tasawuf yang menggunakan pendekatan Abu Yazid Al-Bustami, Al-Hallaj, Suhrawardi Al-Maqtul, ibnu 'Arobi, dan Hamzah Fansuri yang ada di Aceh adalah kelanjutan dari Tasawuf Falsafi, tetapi di pesantren sekarang yang eksis adalah Tasawuf Sunni yang dibatasi oleh al-Junaid al-Baghdadi, yakni attasawufu baytun wassariatu babun. ${ }^{20}$

Efisiensi gerakan tasawuf adalah karena organisasi yang muncul sebagai perkumpulan-perkumpulan tarekat. Tarekat atau thariqah adalah aliran tentang jalan atau cara mendekatkan diri kepada Tuhan. Tarekat tidak membicarakan segi filsafat dari pada tasawuf, tetapi amalan atau praktisnya. Tradisi pesantren mengenal dua bentuk tarekat, yaitu: pertama, tarekat yang dipraktikkan menurut cara-cara yang dilakukan oleh organisasi-organisasi tarekat; dan kedua, tarekat yang dipraktikkan menurut cara di luar ketentuan organisasiorganisasi tarekat. Beberapa organisasi tarekat dapat disebutkan, seperti: Satariyah (dikembangkan oleh Abdurrauf Sinkel dan Abdul Muhyi), Qodiriyah, Naqsabandiyah, Qodiriyah wa Naqsabandiyah, Rahmaniyah,

${ }^{20}$ Transkrip paparan Muhammad Tholhah Hasan, Pesantren dan Sikap Inklusivisme Neosufisme, h. 2 
Rifaiyah, Siddiqiyah, Syadhiliyyah, dan Wahidiyyah. ${ }^{21}$

Menurut Tolkhah Hasan bahwa Walisongo semuanya memiliki pesantren baik pesantren besar maupun pesantren kecil. Semua pesantren Walisongo ada tasawufnya. Dalam primbonnya sunan Bonang disebutkan bahwa yang diajarkan Walisongo adalah fikih yang diajarkan mazhab Imam Syafi'i, aqidah mengikuti imam Al-Asyari dan filsafatnya atau tasawufnya mengikuti aliran imam Al Ghazali. Jadi, lanjut Tolkhah Hasan, jelas bahwa di Indonesia tasawuf yang dibawa ke pondok pesantren adalah tasawuf-tasawuf yang suni, sampai belakangan pengaruh tasawuf di pesantren itu mengalami perubahan. Namun demikian, menurut Muhammad Tholhah Hasan sampai hari ini potensi tasawuf dan pesantren yang menggunakan tasawuf sebagai salah satu alat untuk mengembangkan dan mempertahankan diri masih tetap kuat. Tetapi, daya dorong tasawuf lebih lemah daripada daya tahannya, tasawuf sebagai daya dorong ini belum optimal dibanding dengan tasawuf sebagai daya tahan. ${ }^{22}$

\section{Metode Penelitian}

Penelitian ini bersifat deskriptif-kualitatif. Deskriptif-kualitatif pada umumnya dilakukan pada penelitian dalam bentuk studi kasus. Penelitian deskriptifkualitatif studi kasus merupakan penelitian eksplorasi. ${ }^{23}$ Penelitian dilakukan di Pesan-

${ }^{21}$ Zamkhsari Dhofier. 1982. Tradisi Pesantren: Studi tentang Pandangan Hidup Kiai. Jakarta: LP3ES, h. 136-142

${ }^{22}$ Ibid.

${ }^{23}$ Lihat Burhan Bungin. 2007. Penelitian Kualitatif: Komunikasi, Ekonomi, Kebijakan Publik, dan Ilmu Sosial tren Spiritual Dzikrussyifa' Asma' Berojomusti yang berlokasi di dusun Sekanor, desa Sendangagung kecamatan Paciran Kabupaten Lamongan Jawa Timur. Waktu penelitian lapangan dilakukan pada 3-10 November 2014.

Meskipun tergolong baru dan kecil untuk ukuran pesantren-pesantren di Jawa pada umumnya, atau Lamongan khususnya, pesantren spiritual Dzikrussyifa' menjadi salah satu varian dari ragam atau model pesantren salafiyah yang ingin mengaktualkan potensi tasawuf dalam mendorong pembinaan akhlak umat yang akhir-akhir ini dirasa berkurang. Selain itu, posisi pesantren ini berada dalam wilayah budaya pesisir yang memiliki sifat terbuka dan mobile dan posisi Paciran yang memiliki pesantren Muhammadiyah, di ataranya pesantren Karangasem Muhammadiyah yang disebut Mastuhu sebagai pusat pembinaan kader Muhammadiyah. ${ }^{24}$ Posisi pesantren ini juga berdekatan dengan pesantren Al-Islam Lamongan yang pernah menasional bahkan menginternasional karena kasus Amrozi.

Teknik pengumpulan data lebih mengandalkan pada studi kepustakaan. Keberhasilan studi kepustakaan memengaruhi keberhasilan penelitian lapangan. Penelusuran data primer dilakukan melalui wawancara dengan nara sumber kunci (key informan), pelaku/aktor, mereka yang terlibat dengan berbagai peran yang dimiliki. Saya mewawancarai pimpinan pesantren hampir setiap hari selama saya tinggal di pesantren. Selain

\footnotetext{
Lainnya. Jakarta: Kencana.

${ }^{24}$ Mastuhu. 1994. Dinamika Sistem Pendidikan Pesantren. Jakarta: INIS
} 
itu, saya mewawancarai guru pembimbing dan pihak kemenag kab. Lamongan.

Observasi dilakukan untuk mengangkat realita secara lebih utuh dengan tetap menggunakan pendekatan emik, artinya penelitiberupayamenangkapdanmemahami fenomena yang ada, sebagaimana komunitas Pesantren Dzikrussyifa' memaknai realitas tersebut. Observasi dilakukan terhadap semua kegiatan di Pesantren Dzikrussyifa'. Pesantren Dzikrussyifa sendiri dengan segala aktivitasnya merupakan "teks" yang bisa menjadi sumber data. Observasi dilakukan juga terhadap proses interaksi pimpinan dengan para pasien, masyarakat, penataan fisik, dan gambar-gambar. Pengumpulan data ini dilaksanakan oleh saya sendiri dan dibantu oleh pembantu peneliti. Observasi ke pesantren dilakukan selama 4 hari dan 3 malam.

Analisa data kualitatif dilakukan sebelum, selama dan setelah pengumpulan data. Sebelum dilakukan pengumpulan data, penulis memulai untuk memfokuskan data-data apa yang akan dijadikan unit analisis. Data dan informasi yang terkumpul dikoding dan direduksi kemudian dianalisa sesuai dengan formula kerangka konsep gerakan spiritualitas baik di dunia Muslim maupun khas Indonesia dan lebih khusus lagi spiritualitas di pesantren. Hasil analisa ini selanjutnya diintrepretasi. Hasil penelitian dalam bentuk data penelitian yang dituliskan di sini saya anggap hanya sebagai titik awal dan bersifat permukaan dari realitas yang sesungguhnya. Meskipun digunakan bangunan konseptual, data penelitian atau hasil penelitian yang telah diinterpretasi yang menjadi "pembahasan penelitian" lebih banyak dibantu oleh nara sumber dan informan. Terhadap makna dibalik teks dan simbol yang ada di Pesantren Dzikrussyifa, sedikit yang saya ketahui dan pahami. Karena itu, data-data penelitian yang berupa kata-kata, teks, dan simbol diinterpretasi maknanya oleh saya bersama-sama dengan nara sumber. Hasil analisa dan interpretasi tersebut tersaji dalam "hasil dan pembahasan" berikut .

\section{HASIL DAN PEMBAHASAN}

Uraian akan diawali dengan pemaparan pemaknaan spiritualitas menurut pimpinan Pesantren Dzikrussyifa', kemudian diuraikan salah satu model spiritual yang memengaruhi pemaknaan spiritualitas tersebut. Uraian selanjutnya terkait pengaruh pemaknaan spiritualitas terhadap aktivitas Pesantren Dzikrussyifa'.

\section{Sosok Kiai Muhammad Muzakkin dan Pemaknaan Spiritualitas}

Pesantren Dzikrussyifa' identik dengan sosok Kiai Muhammad Muzakkin (selanjutnya ditulis Kiai Muzakkin). Pemaknaan spiritualitas menurut Pesantren Dzikrussyifa' adalah pemaknaan spiritualitas menurut Kiai Muzakkin sendiri. Meskipun tidak seluruhnya mewakili kelembagaan pesantren, kiai dalam sebuah pesantren adalah unsur kuncinya. Untuk mengetahui siapa sebenarnya sosok Kiai Muzakkin itu dan apa pemikirannya dalam bidang tasawuf, saya melakukan penelusuran baik mewawancarai langsung Kiai Muzakkin maupun data dari buku-buku yang ia tulis dan dari berbagai media.

Kiai Muzakkin dilahirkan di desa Dadapan kecamatan Solokuro kabupaten Lamongan Jawa Timur pada tanggal 5 Juli 1968. Sejak kecil diasuh oleh kedua orang 
tuanya bernama bapak Suparman dan Ibu Darkah. Sebagaimana dituturkan Kiai Muzakkin bahwa dirinya dari garis bapak tersambung ke Jaka Tingkir dan garis ibu tersambung sampai mbok rondo Dadapan yang mempunyai putra yang terkenal bernama Ande-Ande Lumut.

Ia dibesarkan dan dididik dalam lingkungan spiritual, bapak dan ibunya adalah seorang lelaku spiritual. Kalau siang berpuasa dan malam melakukan dzikir, berkhalwat, bertahajud, dan bermujahadah. Selain itu, kedua orang tuanya adalah seorang penganut tarekat Qadiriyah wa Naqsabandiyah yang bermursyid kepada $\mathrm{KH}$ Asrori Al-Ishaqi bin Syekh Usman Al-Ishaqi di Kedinding Surabaya. ${ }^{25}$

Kiai Muzakkin hidup seperti orang pada umumnya. Ia bersekolah TK, MI, MTs, MA, dan mengenyam Perguruan Tinggi. Ia menikah dengan Nurul Hasanah yang berasal dari desa Sendangduwur kecamatan Paciran Lamongan. Pasangan Kiai Muzakkin dan Nurul Hasanah dikarunia 3 (tiga) orang putra-putri: Jayyidatun Nisa al-Muzakkiyah, Akhnaf Farrel al-Muzakki, dan Haikal Azmni al-Muzakki (almarhum).

Sejak kecil sudah diajari dan digembleng oleh orang tuanya serta dikenalkan dengan dunia mistis seperti ditunjukkan kepada

${ }^{25} \mathrm{KH}$ Asrori Al-Ishaqi yang wafat 18 Agustus 2009 adalah mursyid Thoriqoh Qadiriyah wan Naqsabandiyah dan pendiri Pesantren Al-Fithrah Kedinding Kenjeran Surabaya. Ia putra Syekh Usman Al-Ishaqi. Nama Al-Ishaqi dinisbahkan kepada maulana Ishaq, ayah Sunan Giri, karena Syekh Usman masih keturunan Sunan Giri. Ia menjadi mursyid Thoriqoh Qadiriyah wan Naqsabandiyah menggantikan ayahnya, Syekh Usman Al-Ishaqi. Syekh Usman adalah salah satu murid KH Romli Tamim, ayah KH Musta'in Romli, Rejoso Jombang. Lihat suaramerdeka.com, 19 Agustus 2009. alam gaib (bangsa Jin). Itu dilakukan hingga usia remaja. Ketika menjelang dewasa, perjalanan spiritual itu dilanjutkan dengan mengembangkan secara pribadi tetapi masih dalam pantauan kedua orang tuanya. Sehingga apa yang dilakukan Kiai Muzakkin benar-benar matang dan tidak berdampak pada risiko yang negatif (stress karena tidak kuat dengan ilmunya). Pengalaman spiritual itu berlanjut dengan melakukan meditasi di beberapa tempat seperti di makam Walisongo dan tempat-tempat keramat lainnya.

Mengapa perjalanan spiritual ini harus dilakukan di tempat tersebut? Menurut Kiai Muzakin karena di tempat itu terminalnya barang gaib (jin Islam) yang bisa diajak komunikasi untuk kepentingan sesuatu. Dari situlah Kiai Muzakin yang sudah melekat dalam spiritual merasa dekat dengan Allah SWT. Pengalaman beragam spiritual itulah yang melahirkan berdirinya sebuah lembaga yang bernama pesantren yang diberi predikat dengan "spiritual".

Kehidupan keseharian Kiai Muzakin, sebagaimana saya lihat selama berinteraksi dengannya, tidak jauh berbeda dengan kehidupan masyarakat lainnya. Ia menjalani hidup dan bergaul dengan masyarakat yang memiliki status dan tingkatan sosial yang beragam. Suatu hari saya diajak olehnya berkeliling wilayah Paciran baik untuk sekedar makan dan minum di warung kopi maupun untuk diperkenalkan dengan tempat-tempat ziarah seperti masjid dan makam Sunan Sendangduwur, dan lokasilokasi pesantren seperti pesantren Al-Islam Lamongan dan makam Amrozi yang terkenal dengan kasus bom Bali. 
Saat ini, selain sebagai pendiri pesantren spiritual ia juga memimpin sebuah lembaga swadaya masyarakat di antaranya: LCW (Lamongan Corruption Watch), JCW (Jawa Timur Corruption Wacth) dan BPAN-RI (Badan Penyelamat Aset Negara Republik Indonesia). Keterlibatan dalam lembagalembaga tersebut bukan tanpa alasan, karena ia adalah seorang ahli hukum dan dosen pasca sarjana hukum di beberapa kampus di Jawa Timur. Ia juga adalah konsultan hukum yang menangani permasalahan hukum kasus pidana maupun perdata, khususnya dunia korupsi sesuai dengan lembaga yang dipimpinnya. Atas peran dan kiprahnya dalam bidang pemberantasan korupsi, Prof. Nils Bubandt, seorang akademisi dan guru besar Anthropology Aarhus University Denmark, dalam bukunya yang berjudul Democracy, Corruption and The Politics of Spirits in Contemporary Indonesia, mengupas tuntas seputar perjalanan dan kiprah perjuangan Kiai Muzakkin dalam pemberantasan korupsi dengan pendekatan spiritual.

Kiai Muzakkin dapat disebut seorang seniman dan budayawan. Pasca peristiwa bom Bali tahun 2003, Kiai Muzakkin menulis sebuah puisi dengan judul "Jihad Lalat". Puisi tersebut dalam rangka mengkritisi pemahaman tentang berjihad yang dilakukan oleh Amrozi cs. Jihad lalat itu sebagaimana yang tertulis di puisi berikut ini:

\footnotetext{
Jangan kau potong satu pun

Ayat-ayat Allah yang panjang itu

Jangan kau tembak lalat yang menempel di badanku

Hanya untuk kepentingan sesaat
}

\author{
Apalagi dengan meriam dan nuklirmu \\ Apalagi dengan bom dan rudalmu \\ Jangan kau paksa berjihad karena satu lalat \\ Berbahaya \\ Aku mengerti kau pejuang \\ Aku bangga kau penegak kebenaran \\ Kenapa kau potong Ayat-ayat Allah \\ Hingga nyawa melayang tersia-sia \\ Hidup ini berjuang \\ Bukan pembunuhan \\ Kerja baik karena iman \\ Bukan merampok demi Islam \\ Jangan potong satu pun \\ Ayat-ayat Allah yang panjang itu \\ Walaupun kau mampu \\ Buikin dunia jadi abu
}

Secara keseluruhan, isi puisi tersebut mengandung pesan moral terhadap seseorang yang melakukan jihad agar tidak menggunakan ayat-ayat al-Qur'an yang sepotong-potong karena pemahaman demikian akan berdampak negatif terhadap Islam itu sendiri dan masyarakat pada umumnya. Ia juga menulis dua buah judul puisi untuk menggambarkan kota Lamongan, yaitu: Lamongan Mengguncang Dunia dan Lamongan Kota Soto. Judul puisi pertama berisikan Lamongan sebagai sebuah kota yang awalnya dibanggakan menjadi kota yang memprihatinkan karena ada seorang warga Lamongan yang telah menghancurkan pulau Bali. Sedangkan judul puisi yang kedua berisikan tentang keterkenalan satu masakan khas Lamongan, Soto, yang menghiasi dari pelosok desa sampai ibu kota. Selain ketiga puisi tersebut, ia juga menulis judul puisi Perjuangan Belum Selesai yang berisikan curahan sang penulis 
puisi tentang kondisi bangsa dan negara Indonesia, dan puisi berjudul Profesor Kuncir yang ia tulis bagi Prof. Drs. H. Mas Akhmad Ikhsan, seorang dosen Emiritus University of Michigen University of Wisconsin, U.S.A.

Kepandaiannya dalam bidang tarik suara, Kiai Muzakkin membuat sebuah CD lagu yang ia kumpulkan pada saat ia bernyanyi di acara JCW. Lagu favoritnya berjudul Sempurna karya H. Rhoma Irama. Ketika saya tanya mengapa judul lagu sempurna itu adalah favoritnya, ia menjawab: "lagu itu menggambarkan kesempurnaan wanita sebagai bukti kesempurnaan ciptaan Allah, dan menyanyikan lagu itu sebagai bagian dari perjalanan spiritual".

Kisah perjalanan hidup Kiai Muzakkin secara implisit disebut oleh dirinya sebagai "perjalanan spiritual" dalam rangka menjadi “seorang spiritualis". Kisah hidupnya sejak masa kecil, remaja, dewasa, pendiri sekaligus pimpinan Pesantren Dzikrussyifa', pimpinan LCW, pimpinan JCW, pimpinan BPAN-RI, telah membentuk pemaknaannya terhadap spiritualitas. Spiritual didefinisikan dan dimaknai oleh Kiai Muzakkin sebagai upaya untuk menyatukan rahasia ilahi dengan konsep kehidupan rohani melalui pendekatan zikir, berkhalwat, uzlah, bertahajud, bermujahadah, bermeditasi dan berkontemplasi untuk mendekatkan diri kepada Allah sebagai wujud "perjalanan spiritual”. Orang yang menjalankan dunia spiritual, katanya, berarti belajar menyingkap rahasia alam gaib. Setiap orang bisa menjalankan "perjalanan spiritual". Ia mengartikan "perjalanan spiritual" sebagai proses perjalanan mencari Tuhan. Baginya, spiritualitas tidak dibatasi agama, kultur, budaya maupun ideologi.
Menurut Kyai Muzakkin bahwa hasil dari "perjalanan spiritual" adalah menyatunya jiwa dan raga dengan sang maha pencipta. Ia mencontohkan kasus Syekh Siti Jenar (syekh Lemah Abang). Karena tingkat tingginya perjalanan spiritual yang dilakukan Syekh Siti Jenar (syekh Lemah Abang), maka apa yang keluar dari mulutnya hanya katakata Allah, Allah, Allah saja. Menurutnya, bagi masyarakat yang belum memahami spiritualitas akan mengklaim bahwa Syekh Siti Jenar mengaku sebagai Tuhan. Padahal aslinya tidak ada kesempatan untuk berkata lain selain Allah, Allah, Allah dan Allah. Walaupun demikian, di hadapan Allah orang yang melakukan "perjalanan spiritual" sudah digolongkan orang yang mempunyai nilai makrifat itu.

Karena itu, ungkap Kiai Muzakkin, semakin tinggi tingkat spiritualitas maka akan semakin tidak dipahami kecuali oleh orang yang sama-sama mempunyai tingkatan perjalanan spiritual yang selevel. Ia mencontohkan:

Dulu pada saat Nabi Muhammad melakukan Isra Mi'raj dikatakan majnun oleh kaum Quraisy. Karena orang yang mengatakan, tingkat spiritualnya belum selevel. Begitu juga orang yang memahami tentang Gus Dur, jika ilmu spiritual masih jauh di bawahnya maka Gus Dur pun dianggap "tidak waras". Contohnya, pernah difitnah selingkuh dengan seorang wanita, padahal secara logika Gus Dur tidak ada niat untuk berbuat ke arah sana. "Pengetahuan spiritual" menjadi "ilmu spiritual" itu jika sudah dipraktikkan dalam kehidupan sehari-hari melalui pendekatan kontak batin dengan Tuhannya. Jika dulu peristiwa Isra Mikraj Nabi Muhammad tidak masuk akal, tetapi ketika sekarang ini sudah ada Garuda Air, Lion Air dan lain sebagainya, maka 
peristiwa Isra Mikraj bisa disambungkan menjadi sebuah disiplin ilmu yang masuk akal (dunia penerbangan).

Apa arti "pesantren" dan "pesantren spiritual”. Kiai Muzakkin mengatakan bahwa pesantren sendiri merupakan sarana untuk melakukan perjalanan spiritual. Menurutnya, pesantren sebagai sarana dan spiritual adalah isi dari pada perjalanan spiritual itu. Sedangkan Pesantren Dzikrussyifa' adalah faktor sejarah di mana pesantren ini sebelumnya memang dihuni oleh bangsa-bangsa jin dan itu tidak terjadi pada pesantren pada umumnya, selain itu mempunyai ciri khas yaitu: santrinya orang yang sakit jiwa, pencandu narkoba, mantan preman, anak jalanan, dan juga bangsa jin. Kiai Muzakkin memaknai "pesantren spiritual" adalah:

Pesantren spiritual itu: 1) tidak ada di Indonesia bahkan di dunia, 2) adanya hanya di Pesantren Spiritual Dzikrusyifa' Asma' Berojomusti, dan 3) dunia spiritual itu wilayah Allah. Setiap orang berkesempatan untuk melakukan perjalanan spiritual. Bahkan di luar Islam, Hindu dan Budha melakukan perjalanan spiritual. Jika muncul candi Prambanan di Magelang dalam satu malam, itu bukan hal yang aneh. Karena kejadian itu dilakukan melalui proses perjalanan spiritual orang Buddha dan Hindu. Perjalanan spiritual itu dilakukan seseorang akan kehendak Allah. Walaupun orang tersebut tidak beragama Islam.

Jadi, menurut Kiai Muzakkin, pesantren spiritual itu mengadopsi dari rahasia ilahiah. Ia menyatakan bahwa bagi mereka yang belum tahu dunia spiritual itu dianggap hal yang aneh karena mereka tidak tahu apa makna spiritual itu sendiri. Padahal pada diri seseorang mulai dari kandungan ibu sampai ia lahir di dunia dibekali spiritual oleh Allah. Itulah yang seharusnya dipahami oleh semua orang agar bisa mengerti makna yang sebenarnya apa spiritual itu.

\section{Pengaruh Sufi Dunia Islam dan Sufistik ala Walisongo}

Mengapa pemaknaan spiritualitas seperti itu? selain pengalaman kehidupan, ada satu model spiritual yang memengaruhi pemaknaan spiritualitas menurut pimpinan Pesantren Dzikrussyifa', yaitu para sufi dunia Islam dan sufistik ala Walisongo. Salah satu buku yang ditulis Kiai Muzakkin yang berjudul Dzikir Menuju Tasawuf: Penyejuk Hati, Penenang Jiwa dapat menjadi petunjuk bagaimana pemahamannya terhadap tasawuf yang merupakan bentuk spiritualitas Islam.

Ilmu tasawuf, dalam pandangan Kiai Muzakkin adalah sinonim dari ilmu qulub, ilmu asror, ilmu ma'arif, ilmu bathin, ilmu ahwal wa al-maqomat, ilmu suluk, ilmu thariq dan ilmu mukasyafah. Jalan yang ditempuh untuk bertasawuf adalah dengan jalan dzauq (perasaan). Jalan ini berbeda dengan orang-orang salaf, mutakallimin dan filosof. Dengan mengutip imam Suhrawardi, Kiai Muzakkin menguraikan bahwa keadaan atau tingkah laku orang-orang mutashowwifin (kaum sufi) ada dua sebagaimana yang terkandung dalam al-Qur'an surah As-Syuro ayat 13: Allah menarik pada agama itu orang yang dikehendakinya dan memberi petunjuk pada (agama) Nya orang yang kembali kepadaNya. Lebih lanjut, ia mengungkapkan:

Keadaan atau tingkah laku yang pertama adalah jalannya kaum mahbubun-murodun yaitu orang-orang yang dicintai dan dikehendaki Tuhan. Mereka ini adalah 
orang-orang yang mendapat derajat, kenikmatan dan kemuliaan dengan anugerah Allah tanpa dicari sebelumnya. Mereka mendapat kasyaf sebelum ijtihad (berusaha dan tekun beribadah). Setelah Allah menghilangkan hijab dari hati mereka, mereka berijtihad dan beramal serta merasakan lezat atas amal perbuatannya dengan adanya nur yaqin yang telah dianugerahkan Allah di dalam hatinya. Adapun yang kedua adalah jalannya orang-orang yang disebut muhibbun-muridun, yaitu orang-orang yang cinta kepada Allah dan menyiapkan dirinya menuju jalan Allah. Pertama-tama mereka giat dengan ibadah, riyadhoh dan mujahadah, barulah mereka mendapat hidayah yakni kasyaf (tersingkapnya hijab pada hati mereka). ${ }^{26}$

Kiai Muzakkin sependapat dengan Imam Junaid Al-Baghdadi bahwa kaum sufi mencapai makrifah tidak dari kitab atau guru tapi dengan menjalankan dan melaksanakan tasawuf dengan segala latihannya. Dengan mengutip Syeikh Zainuddin bin Ali AlMalibary, ia menyatakan bahwa ada tigajalan yang harus ditempuh dalam bertasawuf, yaitu: Syariat, Tarekat, dan Hakikat. Syariat adalah aturan atau undang-undang dari Allah bagi hambanya baik berupa peraturan atau hukum. Tarekat adalah suatu cara atau pendakian yang ditempuh oleh kaum mutashowwifun untuk mencapai tujuan. Hakikat adalah keadaan salik sampai pada tujuan yaitu ma'rifatullah dan musyahadati nuri at-tajalli (melihat nur yang nyata).

Syariat bagi kaum mutashowwifin tidak bisa ditinggalkan. Terkait dengan syariat ini, Kiai Muzakkin berkata:

26 Lihat Kiai Muhammad Muzakkin. 2005. Dzikir Menuju Tasawuf: Penyejuk Hati, Penenang Jiwa. Pesantren Spiritual Dzikrussyifa' Lamongan, h. 20-21
Syariat adalah salah satu unsur yang harus dilaksanakan, bahkan merupakan hal yang pokok bagi yang lain. Antara syariat dengan hakikat adalah dua hal yang tidak bisa dipisahkan bagi orang bertasawuf, satu sama lain saling berpautan oleh karena itulah kaum mutashowwifun berkata: "sesungguhnya hakikat tanpa syariat adalah batal dan syariat tanpa hakikat adalah tak berarti. $^{27}$

Bagaimana hubungan antara ketiga jalan yang harus ditempuh oleh kaum mutashowwifun. Kiai Muzakkin menyatakan bahwa dalam ilmu tasawuf dikatakan bahwa syariat itu merupakan peraturan, tarekat itu merupakan pelaksanaan, hakikat itu merupakan keadaan, dan ma'rifat itu merupakan tujuan yang terakhir. Ia juga mengumpamakan hubungan tersebut dengan mengutip Imam Nawawi Al-Bantani yang mengatakan hubungan syariat, thariqat, dan haqiqat adalah: syariat ibarat kapal, tarekat ibarat laut, dan hakikat ibarat permata. ${ }^{28}$

Tentang pelaksanaan cara untuk mencapai tujuan, kaum mutashowwifun antara yang satu dengan yang lain adalah berbeda-beda. Salah satu pelaksanaan untuk mencapai tujuan melalui tiga tingkatan, yaitu: tingkatan takholli, yaitu tahkolli nafsi minal ahlaqil madzmumah (melepaskan diri dari akhlak yang tercela). Dari tingkatan takholli ke tingkatan tahalli, yaitu nafsi bil ahlaqil mahmudah (mengisi jiwa dengan akhlak yang terpuji). Dari tingkatan inilah menuju tingkatan tadjalli (kenyataan tuhan).

Pelaksanaan cara untuk mencapai tujuan yang diuraikan Kiai Muzakkin

${ }^{27}$ Ibid., h. 24-25

${ }^{28}$ Nawawi Al-Bantani. 1359 H. Syarh Maraqi al'Ubudiyah. Bandung: Ma'arif, h. 5 
hampir mirip dengan Imam Ghazali yang menggunakan istilah muhlikat dan munjiyat. Muhlikat adalah perbuatan-perbuatan yang membinasakan yang harus disingkirkan, dan munjiyat adalah perbuatan-perbuatan yang menyelematkan yang membawa manusia kepada kebahagiaan yang harus dijalankan. Imam Ghazali memberikan suatu latihan bertingkat yang disebut muroqobah dan muhasabah yang terdiri dari musyarotoh, muroqobah, mujahadah, dan mu'atabah yang akhirnya tercapailah mukasyafah (tersingkapnya hijab antara kholiq dan makhluk).

Apa yang dituju dari jalan yang telah ditempuh? Artinya apa tujuan bertasawuf itu? Untuk masalah ini, Kiai Muzakkin menjelaskan:

Adapun tujuan orang-orang mutashowwifin adalah ma'rifat billah dan insan kamil. Ma'rifat billah adalah melihat Tuhan dengan hati mereka secara jelas dan dan nyata dengan segala kenikmatan dan kebesaranNya, tetapi tidak dengan kaifiyat. Artinya, Tuhan digambarkan seperti benda atau manusia ataupun yang lain dengan ketentuan bentuk dan rupa sebagai jawaban kaifa (bagaimana zat Tuhan?). ...Istilah lain sebagai kata ganti makrifat adalah ru'yah musyahadah dan liqo' ru'yah. Keduanya diperoleh setelah kasyaf. Ma'rifat billah adalah tujuan utama bagi kaum mutashowwifin dan merupakan kelezatan yang paling tinggi....Ma'rifat billah bisa diusahakan (kasab) dengan beberapa tingkatan, dan Ma'rifat billah bisa dicapai dengan adanya nur yang dianugerahkan Allah kepada hati yang bersih sesudah hamba itu terlepas dari belengu nafsu dan kotoran ma'ashi, jadi sekali-kali tidak dicapai dengan pancaindra. ${ }^{29}$

${ }^{29}$ Kiai Muhammad Muzakkin. 2005. Dzikir Menuju Tasawuf: Penyejuk Hati, Penenang Jiwa. Lamongan: h.
Adapun tujuan bertasawuf yang lain adalah insan kamil. Menurut Kiai Muzakkin dengan mengutip konsep-konsep dari Imam Ghazali, Abi Turob An-Nachosyabi, Yahya bin Muad, Muhammad Iqbal, mengartikan insan kamil sebagai manusia yang berjiwa sempurna pada sisi Allah, ia sudah dianggap cukup untuk memberi petunjuk dan menyempurnakan hamba Allah. Ia pergi kepada Allah, ruju' ilallah, ilmuhu min 'indillah. Saya melihat Kiai Muzakkin tidak sependapat dengan konsep insan kamil Ibn Arabi yang menyatakan peleburan diri dzat Tuhan dengan pribadi insan. Meskipun demikian, sebagaimana telah disebutkan, Kiai Muzakkin terlihat membela Syekh Siti Jenar (syekh Lemah Abang) dengan mengatakan bahwa Syekh Siti Jenar melakukan perjalanan spiritual tingkat tinggi. Karena itu, ungkap Kiai Muzakkin, semakin tinggi tingkat spiritualitas maka akan semakin tidak dipahami kecuali oleh orang yang sama-sama mempunyai tingkatan perjalanan spiritual yang selevel.

Selain para sufi, ajaran walisongo dan tokoh-tokoh Islam di Jawa menginspirasi pemaknaan spiritualitas menurut Kiai Muzakkin. Ia mendefinisikan wali sebagai berikut:

Wali adalah ringkasan dari waliyullah, artinya orang yang dianggap dekat dengan Tuhan. Orang keramat yang mempunyai bermacam-macam keanehan. Wali-wali itu dianggap orang yang mula-mula menyiarkan agama Islam di Jawa dan biasa dinamakan Wali Sembilan atau Walisongo. Meskipun jumlahnya banyak dan orangnya juga bermacam-macam. Kebanyakan Wali-Wali itu datangnya dari negeri asing, dari

29-30 
sebelah barat, dari negeri Atas Angin, dari Sumatera. Bahkan ada yang lebih jauh lagi. Sering kali asal-usulnya tidak diketahui orang dengan jelas. ${ }^{30}$

Kiai Muzakkin menggambarkan bagaimana wali-wali itu dalam menyiarkan agama Islam itu tidak menggunakan metode pidato atau ceramah di depan umum. Mereka berdakwah di dalam komunitas-komunitas terbatas bahkan dilakukan secara empat mata yang kemudian diteruskan dari mulut ke mulut. Saat pengikutnya bertambah banyak, muncullah tabligh-tabligh yang diadakan di dalam rumah-rumah perguruan, yang biasa dinamakan pondok. Pendidikan atau cara memberi pengajaran semacam ini pada waktu itu tidak asing lagi, karena dalam masa itu sudah ada mandala-mandala Hindu-Jawa, yang kemudian dinamakan pesantren. Baginya wali adalah orang yang menciptakan hal-hal yang aneh dan ganjil, yang tidak dapat dikerjakan oleh orang lain. Keadaan yang luar biasa itu diperoleh melalui latihan diri dalam pelajaran rahasia dan bertapa untuk mendekatkan diri kepada Tuhan dan menjadi kekasih-Nya sehingga apa yang ia kehendaki tercapai. ${ }^{31}$

Walisongo, ungkap dia, terbagi dalam dua periode, yakni periode pertama adalah para Wali yang bertugas mengislamkan penduduk tanah Jawa yang sebelumnya beragama Hindu-Buddha, sedangkan Walisongo periode kedua adalah para Wali yang bertugas mengatur roda perjalanan Islam di tanah Jawa sebagai tindak lanjut dari usaha-usaha yang telah dirintis oleh para Wali periode sebelumnya. Di antara para Wali yang termasuk periode pertama

\footnotetext{
${ }^{30}$ Ibid., h. 50

${ }^{31}$ Ibid., h. 52
}

adalah: Maulana Malik Ibrahim (Gresik), Maulana Ishaq, Ahmad Jumadil Qubro (Mojokerto), Muhammad Ali Al-Maghribi (Jati Anom), Muhammad Ali Akbar (Cilegon), Malik Isro'il (Cilegon), Hasanuddin (Banten), Aliuddin (Banten), dan Subakir. Sedangkan Walisongo yang termasuk periode kedua, yaitu: Raden Rahmat atau Sunan Ampel (Surabaya), Raden Ainul Yaqin atau Sunan Giri (Gresik), Raden Qasim atau Sunan Drajat (Lamongan), Sayyid Makhdum Ibrahim atau Sunan Bonang (Tuban), Raden Sa'id atau Sunan Muria (Gunung Muria), Ja'far Shadiq atau Sunan Kudus (Kudus), Raden Syahid atau Sunan Kalijogo (Kadilangu Demak), Raden Fatah atau Sunan Demak (Demak), dan Syarif Hidayatullah atau Sunan Gunung Jati (Cirebon). ${ }^{32}$

Pembagian dua periodisasi sejarah Walisongo tersebut tidak banyak dikenal di masyarakat. Nama-nama Walisongo yang dikenal oleh masyarakat selama ini dalam pandangan Kiai Muzakkin termasuk Walisongo periode kedua, meskipun Maulana Malik Ibrahim Ibrahim tidak termasuk dan gantinya dimasukkan nama Raden Fatah atau Sultan Demak. Tidak dicantumkannya tanggal lahir dalam setiap nama Walisongo tersebut menyulitkan untuk diyakini kebenarannya.

Pengaruh ajaran Walisongo terhadap pemaknaan spiritualitas pada Kiai Muzakkin dapat dilihat dari bagaimana ia menggambarkan ajaran-ajaran Walisongo dan tokoh Islam di Jawa dengan cara menuliskan dalam sebuah buku dengan judul Kisah Perjalanan Tokoh Islam di Kawasan

32 Muhammad Muzakkin. 2003. Reaktualisasi Kisah Perjalanan Kehidupan Raden Noer Rachmat Sunan Sendangduwur Paciran Lamongan Jawa Timur. Lamongan: Percetakan Grafika, h. 9-11 
Pantura: Dalam Kajian Pendekatan Perspektif Spiritual. Buku yang diterbitkan tahun 2005 tersebut berisikan beberapa nama Walisongo dan tokoh-tokoh Islam di antaranya; Sunan Drajat, Sunan Sendangduwur, Syekh Siti Jenar, Sunan Kalijaga, Aji Saka dan Sawunggaling.

Bagaimana gambaran dan ajaran wali dan tokoh-tokoh Islam di Jawa tersebut. Kiai Muzakkin menyebut Sunan Drajat sebagai wali yang berjiwa dermawan dan sosial, ahli ukir, dan pencipta Gending Pangkur. Sunan Drajat bersama dengan Sunan Kalijaga berhasil mengislamkan Adipati Semarang Ki Ageng Padan Arang atau Sunan Tembayat (Bayat atau Klaten) dan Tumenggung Cokrojoyo atau Sunan Usman atau Sunan Geseng. Dengan menyajikan Tembang Asmara Dana Sunan Drajat, Kiai Muzakkin menyebutkan bahwa Sunan Drajat tidak memisahkan antara syariat, tarekat, hakikat, dan makrifat. Selanjutnya ia mengungkap hubungan syariat, tarekat, hakikat dan makrifat menurut Sunan Drajat yang digambarkan bahwa syariat adalah mengajak hal yang dhahir, tarekat mengajarkan aspek batiniah dan hakikat mengajarkan bathiniyah dari bathin itu sendiri.

Sedangkan orang yang mencapai tingkat makrifat menurut Sunan Drajat, lanjut Kiai Muzakkin, adalah ibarat bintang yang muncul di siang hari bintang tersebut lenyap atau tenggelam ke dalam cahaya matahari. Dalam hal ini Sunan Drajat menyampaikan sebagaimana dikatakan Kiai Muzakkin:

“..Hiyang jenenge kawula, sirna datan ana keri, pan ilang wujudira, tegese wujude iki, anenggih perlamabang ira, lir lintang karahinan, kasorotan sang hiyang rawi.."
Artinya: Hilang jati diri makhluk, lenyap tiada tersisa, karena hilang wujud, keberadaannya, itulah juga wujud Tuhan, itulah yang ada ini. Adapun persamaannya, seperti bintang di waktu siang, yang tersinari matahari.."

Perumpamaantentang salingtidak dapat dipisahkan ketiga unsur utama, syariat, tarekat dan hakikat oleh Sunan Drajat juga dilakukan oleh para sufi seperti Imam AlGhazali dan ahli fikih sperti Syeikh Zainuddin bin Ali Al-Malibary serta imam Nawawi AlBantani. Perumpamaan tentang perlunya kesinambungan antara syariat, tarekat dan hakikat juga menjadi perhatian utama Kiai Muzakkin dalam pemaknaan spiritualitas. Meskipun dalam perumpamaannya dalam bentuk yang berbeda, tetapi secara substansi perumpamaannya sama, yaitu sebuah penegasan tentang pertautan antara segi lahir (eksoteris) dan batin (esoteris) dalam Islam.

\section{Wujud Kongkrit Spiritualitas: Pesantren Dzikrussifa' Asma' Berojomusti}

\section{Eksistensi Pesantren Dzikrussyifa'} merupakan perwujudan dari pemaknaan pendirinya terhadap spiritualitas. Kiai Muzakkin, sang pendiri, mengaku sebagai orang yang sedang melakukan "perjalanan spiritual" dalam rangka menuju sebagai "seorang spiritualis".

Awal kemunculan dan perkembangan Pesantren Dzikrussyifa' didorong atas kebutuhan banyaknya pasien yang datang untuk berobat melalui pendekatan spiritualitas. Hal inilah yang mendorong Kiai Muzakkin membuat gotaan (kamar-kamar kecil) di rumahnya untuk dijadikan tempat tidur bagi pasien yang datang, dari situlah 
muncul untuk mendirikan pesantren yang bernama pesantren spiritual Dzikrussyifa' Asma' Berojomusti. Proses pendirian pesantren Dzikrussyifa' dan juga beberapa pesantren tua dan besar yang ada sampai sekarang mengikuti proses pendirian zawiyah model Walisongo. Artinya, proses pendirian dimulai dari sekedar pengajian dan bimbingan masyarakat berkembang menjadi kelembagaan pesantren.

Alasan pengambilan kata "spiritual" dalam penamaan Pesantren Dzikrussyifa' sebagai bentuk pengejawantahan dari pemaknaan spiritualitas. Pendirian Pesantren Dzikrussyifa merupakan sebuah "doa" seorang Kiai Muzakkin, dan kata "spiritual” adalah "kebersihan dan kebeningan" dari seorang Kiai Muzakkin yang sedang berdoa. Label "spiritual" dalam nama Pesantren Dzikrussyifa bertujuan untuk membumikan spiritualitas sebagaimana yang terkandung dalam namanya. Sedangkan "Dzikrussyifa" diambil karena berasal dari ayat al-Quran dari kata "zikir" dan "syifa" yang artinya mengingat Allah dan memohon obat kepada Allah. Artinya bahwa setiap kesembuhan hanya berhadap kepada Allah karena sembuh dan tidaknya semata-mata atas rida kuasa ilahi. Inilah yang dinamakan pendekatan spiritual yang dijalankan pimpinan Pesantren Dzikrussyifa dalam konteks tataran ilmu spiritual.

Alasan Asma' Berojomusti dijadikan nama karena itu adalah nama doa yang diwariskan oleh nenek moyang Kiai Muzakkin secara turun menurun dari Joko Tingkir (Anggung Boyo). Asma' Brojomusti adalah nama doa yang diciptakan oleh Joko Tingkir. Do'aKiai Muzakkin kadang-kadang menyebut mantra-Asma' Brojomusti ini diberikan melalui ijazah yang tidak boleh ditulis. Tapi cukup dengan dihafalkan saja. Jadi yang mengetahui adalah orang yang memberi dan yang diberi.

Santri (pasien) yang tinggal di gotaan di rumah Kiai Muzakkin semakin hari semakin banyak dan tidak bisa tertampung lagi menjadikan lokasi pesantren dipindah ke tempat yang baru. Lokasi baru pesantren tidak jauh dari rumah Kiai Muzakkin ke arah selatan kira-kira 100 meter, persisnya di perbatasan kecamatan Paciran dan kecamatan Solokuro. Posisi pesanten ini, jika dilewati dari arah utara Wisata Bahari Lamongan (WBL), sekitar 7 km. Tapi jika dari arah selatan, tepatnya pesantren Al-Islam Tenggulun, kira-kira 1 km. Perpindahan dari lokasi awal ke lokasi yang baru dipenuhi dengan hal-hal spiritual.

Nama Pesantren Dzikrussyifa' muncul di media sekitar pertengahan bulan Juli 2006. Senin 3 Juli Taun 2006, Media Radar Bojonegoro,yang merupakan grup Jawa Pos, mengangkat Pesantren Dzikrussyifa' dengan tulisan "Melihat Ponpes Rehabilitasi Sakit Jiwa dan Pecandu Narkoba, Dzikrussyifa' Asma' Berojomusti Paciran Lamongan". Media itu menceritakan tentang proses penyembuhan orang yang mengalami sakit jiwa dan pecandu narkoba. Berita Mingguan Investigasi Bidik edisi 328/29 Juli-4 Agustus 2006 menurunkan laporannya dengan judul "Pondok Pesantren Rehabilitasi Narkoba". Berita Mingguan itu juga melaporkan tentang proses penyembuhan penyakit jiwa dan pecandu narkoba melalui doa dan zikir.

Selain dikaitkan dengan penyakit jiwa dan pecandu narkoba, awal kemunculan Pesantren Dzikrussyifa' di media juga dikaitkan dengan berita penegakkan hukum terutama dikaitkan dengan sosok Kiai Muzakkin 
sebagai ketua Lamongan Corruption Watch (LCW). Berita Mingguan Investigasi Bidik edisi 330/12-18 Agustus 2006 menurunkan berita tentang warga Desa Banjarwati yang melaporkan dugaan penjualan tanah tak bertuan berupa bukit oleh oknum aparat Desa Banjarwati kepada salah satu warga kota Surabaya dengan harga murah.

Pemberitaan media tentang Pesantren Dzikrussyifa' yang khusus menangani orang yang sakit jiwa dan pecandu serta peranannya dalam penegakan hukum terus berlanjut. Media Posmo edisi 426, 04 Juli 2007 mengangkat Pesantren Dzikrussyifa' yang menyembuhkan orang gila hanya semalam. Harian Radar Bojonegoro, Kamis 3 Juli 2008 mengangkat berita tentang LCW yang berjanji akan mengawal pungli di lingkungan kantor Kementerian Agama Lamongan. Liberty edisi 1-10 Oktober 2008 menulis bahwa Kyiai Muzakkin dipercaya mempunyai tenaga dalam yang mampu menyembuhkan orang-orang gila hanya dengan sekali sentuh. Harian Kompas, Jum'at, 21 November 2008 menulis berita dengan judul "Ponpes Dzikrussyifa, Rumah bagi Pecandu Narkoba dan Sakit Jiwa".

Majalah Liberty edisi 1-10 April 2009 menurunkan kembali laporan tentang Pesantren Dzikrussyifa' dengan tulisannya yang berjudul "Batu Sunan untuk Penyakit Bandel". Media itu menulis:

Berkat olah spiritualnya di Sendang Duwur, HM Muzakkin mendapatkan sebuah batu bertuah yang kemudian diberi nama batu sunan. Batu sunan yang dipadukan dengan kekuatan doa dan tenaga dalam inilah yang menjadi media mengobati berbagai macam penyakit.
Media yang mengaitkan Pesantren Dzikrussyifa' dengan makhluk jin adalah Surya, Jum'at 28 Agustus 2009. Media tersebut menyebut ada 63 jin yang ikut nyantri di Pesantren Dzikrussyifa'. Disebutkan juga di media Surya tersebut bahwa ke63 jin tersebut giat berpuasa dan mengaji. Media lainnya yang menyebut Pesantren Dzikrussyifa' sebagai Pesantren Jin adalah Liberty dalam edisi 1-10 September 2009 dengan laporannya berjudul "Mengunjungi Pesantren Jin Lamongan: Salam Tiga Kali, Jum'at Kliwon Menampakkan diri". Harian Surya, Kamis, 10 Desember 2009 menulis berita dengan judul "1000 Jin ikut Turun Jalan". Surya menulis judul itu dalam rangka hari antikorupsi. Selanjutnya, Liberty dalam edisi 1-10 Januari 2010 kembali menurunkan laporannya dengan judul "Puluhan Jin Dikerahkan untuk Perbarui Tumbal Tanah Jawa". Dalam laporan tersebut, nara sumber yang diwawancarai adalah Kiai Muzakkin. Harian Memo Jumaat Legi, 12 Februari 2010, menulis berita terkait peringatan 40 hari meninggalnya Gus Dur dengan judul "Seribu Jin Doakan Gus Dur".

Pemberitaan Pesantren Dzikrussyifa semakin intens saat ada Pemilihan Umum anggota legislatif 9 April 2014. Media mengangkat Pesantren Dzikrussyifa' karena tidak sedikit calon anggota legislatif yang kalah mendatangi Pesantren itu dengan tujuan yang beragam. Bahkan judul yang diangkatnya pun menggunakan Pesantren Jin, misalnya harian Republika, Kamis, 17 April 2014 mengangkat judul "Caleg Depresi Pun Mengadu Ke Ponpes Jin”. Di beberapa media online diangkat berita Pesantren Dzikrussyifa dengan label Pesantren Jin. Beberapa media online dapat disebutkan di sini antara lain: Merdeka.com, Minggu, 13 April dengan judul 
"Puluhan Caleg Stres Terapi di Pondok Pesantren Jin di Lamongan"; Merdeka.com, Sabtu, 3 Mei 2014 dengan judul "Mengintip pesantren 'Jin' di Lamongan Yang Obati 58 Caleg Stres"; dan Tempo.co, Senin 14 April 2014 dengan judul "Kiai Muzakkin Gunakan Jin Obati Caleg Stres”.

Dari gambaran itu terlihat bahwa awalnya media menyebut Pesantren Dzikrussyifa' hanya sebagai Pesantren rehabilitasi bagi orang yang sakit jiwa dan pecandu narkoba. Tetapi, setelah majalah Liberty edisi 1-10 September 2009 dan diikuti oleh beberapa media lainnya Pesantren Dzikrussyifa' dikaitkan dengan istilah "pesantren jin". Meskipun tidak semua melabeli Pesantren Dzikrussyifa' sebagai Pesantren Jin, media memiliki aspek marketing yang memerlukan suatu berita yang dapat dikonsumsi secara luas oleh masyarakat. Saya mempunyai kesan terhadap penamaan Pesantren Dzikrussyifa' yang dikenal media sebagai Pesantren Jin sebagai “iklan gratis" Pesantren Dzikrussyifa dari media.

Tujuan pendirian Pesantren Dzikrussyifa diilhami oleh salah satu ayat suci al-Quran yang berbunyi: 'ud u ila sabili rabika bilhikmati wal mauidhatil hasanati wa jadilhum billati hiya ahsan (Q,S: An-Nahl, 125). Artinya: ajaklah kepada jalan Allah dengan cara bijaksana dan nasihat yang baik, dan bertukar pikiran. Menurut Kiai Muzakkin, bijaksana (hikmah) di sini oleh para mubaligh dan para kiai belum dipraktikkan secara maksimal bahkan masih jauh dari proporsi yang sebenarnya. Umumnya, kata Kiai Muzakkin, ketika berdakwah hanya di lingkungan pesantren, masjid, musholla dan di mimbar panggung. Padahal mereka itu sudah berada di jalan Allah. Alangkah indahnya orang yang terpinggirkan seperti para penjudi, para pemabuk, para preman, PSK, dan lainlain kemudian diberi dakwah agar bisa ke jalan Allah seperti halnya orang-orang yang sudah ada di dalam masjid dalam rangka melaksanakan perintah-Nya dan menjauhi larangan-Nya. Pastinya itu, ungkapnya, akan lebih arif dan bijaksana (bilhikmah).

Menurut Kiai Muzakkin, Sunan Drajat memberikan konsep empat pilar kehidupan itu juga menerapkan bilhikmah, seperti: (1) menehono teken marang wong kang wuto, (2) menehono mangan marang wong kang luwe, (3) menehono busono marang wong kang wudo, (4) menehono ngiup marang wong kang kudanan. Artinya: (1) berilah tongkat kepada orang yang buta, (2) berilah makan kepada orang yang kelaparan, (3) berilah pakaian pada orang yang telanjang, (4) berilah tempat berteduh kepada orang yang kehujanan. ${ }^{33}$ Pengutipan ajaran Sunan Drajat dalam menjelaskan metode dakwah menunjukkan bahwa ada spiritualitas Walisongo (ajaran dakwah Walisongo) memengaruhi spiritualitas Kiai Muzakkin di dalam menjalankan aktivitas Pesantren Dzikrussyifa'.

Karena itu, tujuan pendirian Pesantren Dzikrussyifa' disesuaikan dengan empat konsep dasar dakwahnya Raden Qasim (Sunan Drajat) tersebut, yaitu: sebagai berikut: (1) mencetak santri yang beriman, bertakwa kepada Allah SWT supaya tidak termarjinalkan di tengah masyarakat, dan (2) memberikan pengajaran keislaman, akhlakul karimah, berkepribadian utuh, mandiri, cerdas, memiliki kemampuan

${ }^{33}$ M. Muzakkin. 2005. Kisah Perjalanan Tokoh Islam di Kawasan Pantura (Dalam kajian Pendekatan Perspektif Spiritual). Lamongan: Pesantren Spiritual Dzikrussyifa Sekanor Sendangagung Paciran, h. 2 
intelektual, prefesionalisme dalam mengembangkan fungsi keagamaan agar tidak menjadi generasi yang dianggap mempunyai kekurangan mental spiritual terus menerus. Tujuan pendirian Pesantren Dzikrussyifa' nampaknya mengikuti modeling Walisogo yang tujuan pendirian "pesantren"nya diorientasikan untuk mengintensifkan dakwah dan pengajaran masyarakat.

\section{Spiritual Kerakyatan}

Menganut paham spiritualitas tidak berarti harus menjauhkan diri dari halhal keduniawian. Melalui pemaknaan spiritualitas tersebut Kiai Muzakkin terlibat dalam penyelesaian permasalahan masyarakat. Karena itu, selain pusat pengobatan, pesantren ini juga terlibat dalam gerakan sosial kemasyarakatan (harakatul ijtimaiyah) seperti LCW (Lamongan Corruption Wacth), JCW (Jatim Corruption Wacth), BPAN-RI (Badan Penyelamat aset negara Republik Indonesia). Lembaga-lembaga itu berkiprah dalam investigasi pemberantasan korupsi, penegakan hukum, dan pelayanan publik. ${ }^{34}$

Lembaga-lembaga itu didirikan atas dasar untuk berdakwah tidak bertujuan untuk mencari kekurangan, kejelekan dan kesalahan orang lain, lebih-lebih bertujuan untuk menghakimi atau menghukum sese-

${ }^{34}$ Beberapa kasus sudah ditangani adalah kasus kasda gate yang melibatkan mantan bupati Sidoarjo Winhindarso yang terjerat dengan hukuman pidana, kasus mega proyek Jabung di kecamatan Laren kabupaten Lamongan dengan melibatkan kepala desa Jabung Roji, dkk terpidana. Sebenarnya, masih banyak kasus-kasus yang sedang ditangani oleh Kiai Muhammad Muzakkin diantaranya: mega proyek PT Aplus Perusahaan Malaysia di desa Prupuh kecamatan Panceng kabupaten Gresik yang kasus ini sampai saat ini ditutup oleh Buapati Gresik Sambari Halim atas laporan JCW ke KPK. orang tetapi media untuk berdakwah dengan cara yang dilakukan oleh Rasulullah SAW sebagaimana dalam haditsnya "Man roa minkum munkararon falyugoyyir biyadih, failam yastathi fa bilisanihi, failam yastathi fa biqolbihi wahuwa adha'ful iman". Artinya: barang siapa dari kamu semuanya yang melihat kemungkaran, maka rubahlah dengan tanganmu (kekuasaan), jika tidak mampu maka rubahlah dengan lisanmu, dan jika tidak mampu rubahlah dengan hati. Hal itu adalah selemah-lemahnya iman.

Lembaga-lembaga tersebut memiliki moto "dicari karena berani, bicara karena fakta”. Menurut Kiai Muzakkin, moto itu dimaksudkan jangan berani karena dibayar atau ada orang yang membekingi. Apa yang dilakukan juga harus berdasarkan fakta yang valid. Visi dan misinya diarahkan untuk berdakwah dan dalam rangka menyampaikan risalah Rasulullah agar umat bisa berbuat baik dan taat terhadap hukum baik urusan negara maupun akhirat. Unsur spiritual dalam visi dan misi lembaga-lembaga ini diejawantahkan dengan ditekankan prilaku ajaran yang benar yang berorientasikan "keakhiratan". Di sini nampak ada spiritualitas dan kesinambungan antara doa "robbana atina fiddunya khasanah wa fil akhierati hasanah waqina 'adabannar". Artinya, ya Allah ya tuhanku berilah kami kebaikan di dunia dan di akhirat serta jauhkanlah kami dari siksa api neraka.

Menghubungkan LCW, JCW, dan BPAN-RI dengan spiritualitas merupakan bentuk konkret dari konsep Rasulullah tentang "khoirunnas anfauhum linas" yang artinya sebaik-baiknya manusia adalah orang yang paling bermafaat bagi manusia lainnya. Inilah mengutip istilah Tolkhah 
Hasan yang saya sebut-meskipun agak berlebihan-sebagai "Tasawuf Kerakyatan". Tasawuf kerakyatan atau gerakan spiritual kerakyatan diwujudkan dengan banyaknya orang yang mempunyai kasus hukum dan problem rumah tangga yang minta bantuan pendampingan dan solusi spiritual yang bersifat magic agar apa yang menjadi problemnya bisa teratasi dan dimenangkan di pengadilan.

Pembiasaan dan pembudayaan spiritual kerakyatan melalui beberapa praktik keagamaan seperti: sering menjalankan puasa senin-kamis, tidak tidur sore, banyak berzikir dan menjauhi perilaku maksiat agar hidup lebih tenang dan selalu dalam lindungan Allah SWT. Spiritual kerakyatan mensyaratkan adanya pemahaman tentang hukum, sosial, budaya, dan kemampuan SDM terutama Agama. Nilai spiritual kerakyatan di Pesantren Dzikrussyifa' di antaranya adalah mengembangkan ajaran inti tasawwuf yaitu: sabar, nriman, loman, akas, temen. Yang artinya sabar itu adalah menjalankan perintah dan menjauhi larangan. Nriman adalah identik dengan qanaah, loman identik dengan shadaqoh, akas identik dengan berkarya, dan temen identik dengan konsisten. Kelima ajaran tasawuf kerakyatan Pesantren Dzikrussyifa' terpampang di gerbang pintu saat kita akan masuk ke dalam Pesantren Dzikrussyifa'.

\section{PENUTUP}

\section{Kesimpulan}

Pimpinan Pesantren Dzikrussyifa, Kiai Muzakkin memaknai spiritualitas lebih dekat kepada pemahaman istilah sufisme (tasawuf) atau dengan aspek yang lebih praktis dari tasawuf, yakni tarekat. Karenanya, secara teoritis dan filosofis sufisme Imam AlGhazali, Imam Al-Junaid Al-Baghdadi dan Walisongo memengaruhi Kiai Muzakkin dalam memaknai spiritualitas. Jika ditakar melalui konsepsi tasawuf Sunni dan tasawuf falsafi, pemaknaan Kiai Muzakkin terhadap spiritualitas dipengaruhi oleh tasawuf Sunni. Artinya, Pemaknaan spiritualitas ini diilhami oleh eksistensi sufisme atau tarekat yang sudah lama berkembang di pesantren.

Aktivitas spiritual sudah dimulai sejak akan didirikannya pesantren. Pendirian pesantren dimaksudkan untuk mencontoh tujuan "pesantren" Walisongo. Mengacu kepada polarisasi tarekat elitis dan tarekat rakyat sebagaimana dipopulerkan oleh Tolkhah Hasan, Pesantren Dzikrussyifa' mengambil jalan yang kedua, yakni tarekat rakyat. Pengambilan tarekat rakyat ini untuk mengisi model tasawuf yang terasa kurang daya dorongnya. Pesantren Dzikrussyifa' sedang-mungkin akan terusmengorientasikan aktivitasnya kepada "spiritual kerakyatan". Karenanya, peran dan fungsi Pesantren Dzikrussyifa', tidak sekedar sebagai pusat pendidikan tetapi sebagai pusat bimbingan spiritual dan pusat rehabilitasi narkoba, bahkan sebagai pusat bantuan hukum. 


\section{Saran dan Rekomendasi}

Dari kesimpulan tersebut, penulis menyarankan: pertama, spiritualitas model Pesantren Spiritual Dzikrussyifa' Asma' Berojomusti dapat dijadikan model pengembangan daya dorong potensi tasawuf oleh pesantren-pesantren lainnya. Kedua, Pengembangan spiritualitas oleh Pesantren Dzikrussyifa' bisa dijadikan model pengembangan pendidikan karakter dan pendidikan multikultural yang selama ini didengung-dengungkan oleh publik. Ketiga, melakukan penelitian tema yang sama dengan pesantren yang berbeda.

\section{SUMBER BACAAN}

\section{Buku dan Makalah}

Al-Bantani, Nawawi (1359 H): Syarh Maraqi al-'Ubudiyah. Bandung, Ma'arif,

Bungin, Burhan (2007): Penelitian Kualitatif: Komunikasi, Ekonomi, Kebijakan Publik, dan Ilmu Sosial Lainnya. Jakarta, Kencana.

Bruinessen, Martin Van (1999): Kitab Kuning, Pesantren dan Tarekat: Tradisi-Tradisi Islam di Indonesia. Bandung, Mizan,

Dhofier, Zamkhsari (1982): Tradisi Pesantren: Studi tentang Pandangan Hidup Kiai. Jakarta, LP3ES.

Hanafi, Muchlis Hanafi, et.al (editor) (2010): Spiritualitas dan Akhlak, Lajnah Pentashihan Mushaf Al-Qur'an Badan Litbang Dan Diklat Kementerian Agama.

Hasan, Muhammad Tholhah (2010): Pesantren dan Sikap Inklusivisme Neosufisme, Makalah tidak diterbitkan yang disampakain dalam halaqoh ulama, Pesantren Sebagai Pusat Peradaban Islam, Bogor 13-14 Desember.

John, A.H (1961): "Sufism as a category in Indonesian Literature and History", dalam JSEAH,2.

Lombard, Denis (2005): Nusa Jawa: Silang Budaya, Bagian II Jaringan Asia. Jakarta, Gramedia Pustaka Utama.

Madjid, Nurcholis (1974): “Tasauf dan Pesantren", dalam Dawam Rahardjo (ed), Pesantren dan Pembaharuan. Jakarta, LP3ES.

(2009): Kaki Langit Peradaban Islam, Jakarta, Paramdina bekerjasama dengan penerbit Dian Rakyat

Mas'ud, Abdurahman (2006): Dari Haramain Ke Nusantara: Jejak Intelektual Arsitek 
Pesantren. Jakarta, Kencana Prenada Media Group,

Mastuhu (1994): Dinamika Sistem Pendidikan Pesantren. INIS, Jakarta.

Muzakkin (2003): Reaktualisasi Kisah Perjalanan Kehidupan Raden Noer Rachmat: Sunan Sendangduwur Paciran Lamongan Jawa Timur, Grafika.

(2005): Kisah Perjalanan Tokoh Islam di Kawasan Pantura: Dalam Kajian Pendekatan Perspektif Sipiritual, Lamongan, Pesantren Spiritual Dzikrussyifa Lamoingan.

(2005): Dzikir Menuju Jalan Tasawuf, Lamongan, Keluarga Besar Asma' Berojomusti Pesantren Spiritual Dzikrussyifa' Sekanor Sendangagung Paciran Lamongan

(2005): Rahasia Alam Kubur: Keberadaan Jenazah \& Perlakukan Malaikat, Lamongan, Keluarga Besar Asma' Berojomusti Pesantren Spiritual Dzikrussyifa' Sekanor Sendangagung Paciran Lamongan

(2009): Merakit Kembali Sejarah Berserakan; Siapa Raden Noer Rachmat Sunan Sendangduwur?, Lamongan, Tim Investigasi JCW kerjasama dengan LCW dan Lembaga Pondok Pesantren Dzikrussyifa' Asma' Berojomusti.

Ricklefs, M.C (2012): Mengislamkan Jawa: Sejarah Islamisasi di Jawa dan Penengtangnya dari 1930 sampai sekarang. Jakarta, Serambi Ilmu Semesta

Shihab, Alwi (2009): Antara Tasawuf Sunni \& Tasawuf Falsafi: Akar Tasawuf di Indonesia. Depok, Pustaka Iman.

Soebardi, S (1978): “The Pesantren Tarikat of Suralaya", dalam S.Udin (ed), SPECTRUM. Jakarta, Dian Rakyat.

\section{Media Cetak dan Media Online}

Bidik edisi 328/29 Juli-4 Agustus 2006

Bidik edisi 330/12-18 Agustus 2006

Kompas, Jum'at, 21 November 2008

Liberty edisi 1-10 Oktober 2008

Liberty edisi 1-10 April 2009

Liberty, edisi 1-10 September 2009

Liberty, edisi 1-10 Januari 2010

Memo, Jumat Legi, 12 Pebruari 2010

Posmo edisi 426, 04 Juli 2007

Radar Bojonegoro, Senin 3 Juli 2006

Radar Bojonegoro, Kamis 3 Juli 2008

Republika, Kamis, 17 April 2014

Detiksurabaya.com, Rabu, 9 Desember 2009

Kompas.com, Rabu, 26 Agustus 2009

Kompas.com, Minggu, 27 September 2009

Merdeka.com, Minggu, 13 April 2014

Merdeka.com, Sabtu, 3 Mei 2014

Okezone.com, Senin, 7 September 2014

Suaramerdeka.com, 19 Agustus 2009.

Surya, Jum'at, 28 Agustus 2009.

Surya, Kamis, 10 Desember 2009

Tempo.co, Senin 14 April 2014 